LUBLIN STUDIES IN MODERN LANGUAGES AND

LITERATURE 38 (2), 2014, HTTP://WWW.LSMLL.UMCS.LUBLIN.PL

\author{
Magdalena Kałuża \\ Maria Curie-Skłodowska University \\ Plac Marii Curie-Skłodowskiej 5, \\ 20-030 Lublin, Poland
}

\title{
Образ колдуна Боровика в рассказе Русалка Ореста Сомова
}

\begin{abstract}
The article analyses the image of Borovik the Sorcerer (Боровик) in the short story Pусалка (Water Nymph, 1829) by O. Somov from the perspective of the demonological discourse construed as the use of language, the means to communicate ideas and the interaction of individuals in the society in the Russian literature of the Romanticism in the context of Slavic national demonology. The author shows that the image of Somov's sorcerer was constructed according to the criteria of the unique socio-cultural phenomenon - Russian sorcery (русское колдовство). Particular attention was paid to Borovik's external appearance, his behaviour towards, and interactions with other characters (Gorpinka the water nymph and her mother), his ways of building authority and the relationship of power that existed between him and the local community. In the overall context of Slavic folklore the author analyses also functions of animals that play the role of the sorcerer's minions. In the final section the article points out the link of the analysed image with the Romantic preoccupation with the common people, as well as literary freneticism.
\end{abstract}

Литературный образ колдуна в Русалке Сомова (1829) отражает типичный для культуры восточных славян процесс синтеза языческой мифологии и православного христианства. В науке он определяется как особый социокультурный феномен - 
русское колдовство. Феномен этот характеризовался, во-первых, верой в чрезвычайную близость святых угодников и сверхъестественных покровителей к человеку и в их благожелательность по отношению к колдующему, во-вторых, своеобразной утилитарностью колдовства. Восточнославянские колдуны не искали абсолютных знаний, а довольствовались полезной магией. Поэтому, между прочим, они занимают промежуточное положение между европейским чернокнижием и азиатским шаманством (Даль 2002: 5-6).

Сюжет Русалки основывается на предании о перемене в демоническое существо утонувшей с горя молодой девушки. Живущая в лесу с матерью Горпинка влюбилась в польского пана Казимира, который обещал на ней жениться. Спустя год, когда он не возвращался, девушка пошла в лес за советом колдуна Боровика и домой уже не вернулась. Оставшаяся одной мать Фенна тоже решила просить помощи у колдуна и по его указаниям отыскала дочь, но та уже оборотилась русалкой. Попытка утащить ее из леса домой закончилась тем, что русалка год просидела у печки мертвецом, а следующей весной, на Троицкой (Русальной) неделе, убежала с подругами-русалками.

В тексте нет сцены непосредственной встречи девушки с колдуном, то возникает впечатление, что именно он является зачинщиком перемены Горпинки в русалку. В художественном мире произведения колдун является самым могучим эвокатором демонологических ассоциаций. Само упоминание этого лица связано с ростом эмоционального напряжения и предвещанием угрозы, что подчеркивается описанием природы:

Осенний ветер взрывал волны в Днепре и глухо ревел по бору; желтый лист, опадая с деревьев, с шелестом кружился по дороге, вечер хмурился на дождливом небе, когда Горпинка пошла к колдуну. (Сомов 1984:138) ${ }^{1}$

В данной цитате повторяются ранее использованные слова, описывающие место жительства колдуна: за Днепром, в бору, в

\footnotetext{
${ }^{1}$ В дальнейшем текст цитируется по этому изданию с указанием страниц в квадратных скобках.
} 
глухом месте - в Днепре, глухо, по бору. Длинный и сложный путь к колдуну, который проходит неопытная девушка, подчеркивает лиминальность ее состояния в момент перемены и позволяет интерпретировать его как инициационный путь к зрелости. Читателю кажется, что колдун, как самый компетентный персонаж произведения, ведет Горпинку к себе по извилистому пути, становившемся бездорожьем². Встречаемые ею по дороге лиственные вихри и дождевые тучи осложняют ей выбор, делают из нее существо безвольное, потерянное, в прямом и психологическом смысле. Вечер, в который девушка пошла к колдуну, становится осенью ее жизни.

Порывистый ветер, независимо от того, является ли он проявлением колдовства Боровика, несомненно подготавливает трансформацию Гопинки в русалку. Стоит отметить, что славянские верования связывали возникновение ветра с самоубийством ${ }^{3}$, самоубийство (в частности, молодой девушкиутопленницы), с переменой в русалку.

Характеристика колдуна концентрируется, с одной стороны, на создании чувства страха, с другой стороны подчеркивает его неоднозначный, но автономный статус и веру в его могучую силу. Обращение к нему за помощью связано с сознательным риском. Л. Виноградова отмечает: «Функция „вредить человеку” включается в основной состав признаков полесского колдуна. [...] Вместе с тем, [...] о колдуне чаще говорили, что он может как вредить, так и помогать людям.» (НДП1 2010: 286-287). В

\footnotetext{
2 «Колдун заводит людей на бездорожье» (НДП1 2010:301).

Л. Виноградова ссылается на исследования польского ученого К. Мошиньского, который без всяких сомнений утверждает, что народ отождествляет внезапное появление порывистого ветра с самоубийственной смертью или со смертью колдуна. Среди славян массовыми являются верования о том, что в ипостаси ветра или вихря летают души людей, умерших «не своей» смертью и не умевших найти себе места на том свете, так как их «небо не принимает». (НДП2 2012: 12, 422, 425-429; Виноградова 2000: 85-86; Pełka 1987: 53).
} 
связи с этой амбивалентной функцией колдун пользовался большим уважением среди членов сельского общества.

В художественном мире Русалки авторитет колдуна строится прежде всего с помощью страха. Обе его посетительницы (дочь и мать) боятся его, но ни одна из них не сомневается в том, надо ли или не надо идти к нему за помощью. Более того, не идти к колдуну значит пренебречь им и нарушить общественное предписание считать его непререкаемым авторитетом в решении жизненно важных проблем. Такое мировоззрение наблюдается в словах услужливых старушек - соседок: «он-де скажет тебе всю правду и наставит на путь, на дело!» Использованные языковые конструкции имеют характер обобщающей персвазии и скрытой манипуляции. Хорошо видна при этом и неоднозначность общественного восприятия личности колдуна. Непонятно, чем и как именно он поможет, но силой своего авторитета укажет любой путь, любое поведение, устраняя томительное бессилие, неуверенность, апатию, отчаяние. Такие чувства мучают несчастную Горпинку, и она легко поддается внушениям старушек, желая изменить свое положение. Пусть кто-то другой сильнее и умнее нее - решает, что делать. Весьма знаменательно, что писатель дважды использует слово наставить: «старушки наставили дочь идти к колдуну», а тот должен ее «наставить на путь, на дело». Хорошо отображает это безволие, несамостоятельность героини.

Другая мотивировка управляет поведением матери. Ее жизненный опыт сказывается на ее расчетливости, она действует методически, взвешивая всякую пользу и угрозу. «Кто тонет, тот и за бритву рад ухватиться, говорит пословица. Старуха подумала, подумала - и пошла в бор.» [139]

Несмотря на решительность и уверенность в себе, также она подвержена «пытке страхом». Когда она увидела Боровика, «волосы у нее поднялись дыбом и лихорадочная дрожь ее забила...» [139], а при расставании с ним «чуть не упала от испуга» и «дрожащими ногами поплелась из бора» [141]. Эпитет «страшный» появляется в описании колдуна несколько раз: в 
отношении его самого («страшный старик»), его местожительства («в страшном подземелье или берлоге»), а также его помощницыжабы («проквакала страшным голосом»; «страшно на нее [вдову - M.K.] покосилась»). Страх выступает здесь элементом, конституирующим демонический имидж колдуна, подчеркивающим его авторитет и строящим эмоциональное напряжение между ним и его посетительницей. Как кажется, вдова «разыгрывает» этот страх, что позволяет относить его скорее к категории ритуала или своеобразного савуар-вивра, чем к психологической мотивировке действий персонажа. Кроме страха, демонический авторитет Боровика строится с помощью атмосферы таинственности и недосказанности:

Никто не знал, откуда он был родом, когда и как зашел он в заднепровский бор и сколько ему лет от роду; но старожилы киевские говаривали, что еще в детстве слыхали они от дедов своих об этом колдуне, которого с давних лет все называли Боровиком: иного имени ему не знали. [139]

Примененные писателем глаголы в множественном числе (говаривали, слыхали, называли, не знали) и обобщающие по своему характеру местоимения никто и все ссылаются на собирательное сознание, воздействие которого намного сильнее единичного влияния.

Боровик - это старец, непонятно в каком возрасте. Но из текста следует, что он живет дольше, чем средний смертный, и его жизнь приближается уже к концу. Долговечность укрепляет профессиональный авторитет колдуна и внушает сильную связь с нечистой силой.

Эта связь вытекает из соотнесенности колдуна с потусторонним миром, поэтому в его характеристике присуща хтоническая символика.

Так, он живет в «страшном подземелье или берлоге», он же сам представлен как «скрюченный, сморщенный старик, словно выходец с того света». Вместо обычной речи, их его рта выходят хрипящие, еле слышные звуки, «как будто б этот голос выходил из могилы» [140]. Весьма знаменательно, что Фенна увидела его лежащим на голой земле, в полном солнце, в майский жаркий 
полдень, прикрытого шубами, как будто он не мог согреться. Все это указывает на преагональное состояние Боровика, находившегося на границе жизни и смерти, что придает ему особый, лиминальный статус посредника между миром живых и мертвых, людей и демонов. Холод, испытываемый Боровиком, с одной стороны является физиологическим признаком приближающейся кончины, с другой стороны он символизирует перехват тела и души колдуна демонами, которые по своей природе холодны (Махов 2013: 128-129). Своеобразная «профессиональная перегрузка» и бремя контракта с нечистой силой обуславливает продолжительную и тяжелую смерть. Это подтверждается в народных преданиях, становясь характерной функцией персонажа (Никитина 2002: 391-392).

Интересным пространственным символом является использованный в описании колдуна круг.

Около него был очерчен круг, в ногах у колдуна сидела огромная черная жаба, выпуча большие зеленые глаза; а за кругом кипел и вился клубами всякий гад: и ужи, и змеи, и ящерицы; по сучьям деревьев качались большие нетопыри, а филины, совы и девятисмерты дремали по верхушкам и между листьями. [140]

Оставляя пока что в стороне хтоническую и демонологическую символику этого бестиария, заметим, что он сосредоточивается вокруг колдуна в очередных кругах. При этом сам колдун предостерегает вдову: «Не входи в круг!» Круг - это очень сильный магический и апотропеический символ, защищающий того, кто помещен внутри его. Возникает впечатление, что колдун, будучи в преклонном возрасте, обремененный опытом частых контактов с нечистью, не в силах отбивать уже нападения демонов, поэтому скрылся от них внутри круга.

Демонический бестиарий, заметив вдову - чужого, вступающего на территорию колдуна - начал бить тревогу со своеобразным шумом и волнением:

Лишь только появилась старуха - вдруг жаба трижды проквакала страшным голосом, нетопыри забили крыльями, филины и совы завыли, змеи зашипели, высунув кровавые жала, и закружились быстрее прежнего. [140] 
Как отмечают ученые, движение, беспокойство и шум входят в состав основной характеристики демонов. Российский исследователь средневековой христианской демонологии А.Е. Махов пишет: «Одно из проявлений присущего демонам постоянного беспокойства $[\ldots]$ - их пристрастие к шуму. Явление демонов, как правило, сопровождается страшным грохотом и другими шумами; сами демоны имитируют звуки всевозможных животных.» (Махов 2013: 60-63, 366).

Присмотримся к свите колдуна Боровика в произведении Сомова. Ее состав, как оказывается, довольно типичен; Сергей Максимов, известный собиратель верований и обычаев русского народа, в своей книге Нечистая, неведомая и крестная сила (1903) среди помощников колдунов и ведьм называет: «филины, совы, черные, без всякого пятнышка, кошки, лягушки, змеи и всякие пресмыкающиеся гады безразлично» (Максимов 2002:232). Все эти животные появляются и в сомовской Русалке, при чем четко замечается их иерархия, выражающаяся в соответственном размещении их в пространстве. Важнейшую роль выполняет большая черная жаба с выпуклыми глазами, «правая рука» Боровика. Она сидит у него в ногах, внутри круга, не сводит с него глаз и выполняет все его приказы: скачет в подземелье и приносит оттуда во рту магические приборы, т.е. клык черного вепря и черную свечу. Так, своей способностью понимать и выполнять приказы жаба приобретает здесь антропоморфические черты, что позволяет видеть в ней олицетворение ведьмы или колдуньи. Ибо, как указывают многие источники, в народной традиции жабы и лягушки часто считались ведьмами в связи с их хтонической и демонологической символикой (РМЭ 2006:297). Одной из основных функций восточнославянской ведьмы было ее умение оборачиваться любым животным, в том числе жабой, особенно черного цвета (НДП1 2010:123). Тоже согласно общехристианской символике жабы были атрибутами дьявола (Cooper 1998:231). В анализируемом произведении жаба является единственным животным, которое удостаивается чести 
услуживать колдуну и которое свободно пересекает в обе стороны границу магического круга. Остальные «бестии» это обычная «нечисть», которая не допускается во внутрь круга и исчезает по его повелению. Жаба помогает колдуну в его работе, поэтому не исчезает с остальными. Она интеллигентна, послушна, способна укрепить авторитет колдуна: при появлении вдовы она «трижды проквакала страшным голосом», выполняя его приказы «завертела глазами», а в момент, когда колдун строго наставляет женщину, «жаба страшно на нее покосилась и захлопала уродливым своим ртом». Таким образом в словах и жестах персонажей проявляется демонологический дискурс.

Отдельную категорию демонических помощников колдуна составляют рептилии и «всякий гад»: «и ужы, и змеи, и ящерицы». Они появляются в совокупности, как вьющееся, шипящее, высовывающее кровавые жала скопище, ассоциирующееся с адом.

Внимания заслуживают перечисленные Сомовым маленькие птички сорокопуты. Как объясняет автор в примечании, эти птицы повсеместно выступали в украинских лесах и являлись предметом многих суеверий, связанных со смертью. Они касались, прежде всего, их обычая убивать несколько жертв сразу и оставлять их в качестве припасов, оттуда их обычное название девятисмерты. Встречу с сорокопутом считали предвещанием скорой смерти, от которой защищались специальными заговорами ${ }^{4}$.

В свите колдуна появляются и нетопыри, прямо ассоциирующиеся со смертью, ночью, кладбищами и чернокнижием; считались также олицетворением упырей и ведьм, а даже самой Сатаны (Соорег 1998:176). Наконец, совы и филины во многих культурах считались символом зла, тьмы,

\footnotetext{
4 Zob. http://about-kiev.ru/povedai5.html (19.08.2013). Сегодня известным является факт, что сорокопуты накалывают своих жертв на шипы, чем помогают себе разделять их на куски и делать своего рода кладовую с припасами. См. http://wyborcza.pl/2029020,75400,11181061.html (19.08.2013).
} 
ночи, одиночества и плохого предзнаменования. Они олицетворяли Сатану, а их гуканье предвещало смерть (Cooper 1998:257-259). Можно предполагать, что выбор писателем столь знаменательного бестиария в качестве свиты колдуна несомненно обоснован желанием экспонировать связь этого персонажа со сферой смерти.

Когда вдова появилась в жилище Боровика, вся его свита начала кричать, выть, визжать и шипеть, и исчезла после того, как Боровик «махнул черною ширинкою с какими-то чудными нашивками красного шелка». Ширинка (рушник) - это продолговатый кусок ткани с богатой вышивкой, выполняющий в народной культуре восточных славян обрядовые и магические функции. Ширинки использовались в свадебных и похоронных обрядах, при родинах и крестинах, в магии и медицине. Как символ пути, они являлись лиминальным символом: означали путь умершего на «тот свет» и воспринимались как «окно» между живыми и мертвыми ${ }^{5}$ Несомненно, такие коннотации прослеживаются в анализируемом произведении, ибо колдун это лицо на границе жизни и смерти. Магические функции ширинки подчеркивают богатые орнаменты вышивки и ее расцветка. Цветовая оппозиция красный - черный в системе верований славян использовалась во многих магических обрядах в связи с ее символикой (Libera 1987: 127-128). Небезынтересна также мифологическая функция нити и ткани в обрядности славян. Им придавались значения, связанные с жизнью и смертью. Кроме того, всякое рукоделие как таковое относили к деятельности ведьм, колдунов и знахарей (Криничная 2004: 463-493). В контексте вышесказанного кусок черной ткани с вышитым красным шелком узором в руках колдуна Боровика приобретает значение магического предмета очень высокого ранга.

Вдова обращается к колдуну формулой пан-отче, которая определяет социальную связь между ними, основанную на одностороннем уважении к неопровержимому авторитету.

\footnotetext{
${ }^{5}$ Cм. http://ru.wikipedia.org/Wiki/Рушник (19.08.2013).
} 
Посредственно это уважение проявляется также в поведении, внешнем облике и осанке женщины. Она описывается как «дряхлая, оробевшая женщина», которая дрожит от страха, не говорит без вопроса, всей собой приобретая умоляющий вид просительницы, удостоившей чести получить аудиенцию у могучего мага. Боровик выражает, разумеется, совсем противоположную позицию. Обращают внимание используемые им формы обращения: второе лицо единственного числа, повелительное наклонение, очень частые личные и притяжательные местоимения (mbl, твой). Его речь основана на языковых правилах приказа и запрета, выражающих отношения власти и верховенства колдуна над вдовой (и шире - над всей местной общественностью), а также его самоуправство, бездушный цинизм и чувство силы, способной преодолеть всех и все. Колдун строго приказывает Фенне сохранять в тайне все действия с ее участием и не служить молебнов в церкви. Пренебрежительное использование возвратного местоимения («не сказывай своим попам да монахам») и так же пренебрежительные поп, монах в множественном числе несет с собой очень сильную информацию. Запрет служить панихиду убеждает вдову в том, что Горпинки уже нет в живых. Несмотря не это, она после «проводов» своей русалки должна ждать год, во что бы то ни стало. Дальнейшее развитие сюжета показывает, что спустя год вегетации в доме матери в облике мертвеца Горпинка убегает к «своим», т.е. к русалкам. Так, хотя указания Боровика оказались в известной мере эффективными, окончательный эффект оставлял желать лучшего. Кажется, всемогучий маг подтрунил над горем обеих женщин под предлогом оказания им помощи.

Показательно, что вдова не принесла с собой ничего в качестве оплаты за услугу, сам колдун тоже не требует с ней вознаграждения. Фенна не платит даже за полученные от него предметы, имеющие ведь материальную ценность. Можно предполагать, что общественное отношение между колдуном и вдовой (и местным обществом) выходит за рамки договорного 
отношения, существенными составляющими которого являются товар (услуга) и цена. Трудно, однако, поверить, чтобы маг помогал бескорыстно. В чем он мог усматривать свою выгоду? Возможно, он хотел перед смертью передать часть обременяющих его, тягостных знаний, освободиться от мучающих его угрызений совести; или просто, он имел в виду укрепление собственного авторитета. Или предполагал создать русалку. Боровик явится в этом контексте как настоящий сатанинский демиург.

Выразительная сцена встречи Фенны с Боровиком и следующая за ней сцена магических действий с русалками является композиционной доминантой всего произведения. В художественном мире Русалки с помощью персонажа колдуна раскрывается особая общественная иерархия, в которой он занимает первостепенное место, важнее православных монахов и священников, мирно и дружно существующих рядом с его территорией в своих величественных монастырях и уединенных скитах. Но в кризисных ситуациях окончательной инстанцией всегда является колдун и поэтому его роли в демонологическом дискурсе произведения нельзя не оценить должным образом.

В итоге наших рассуждений соотнесем образ Сомововского колдуна с русской и европейской литературной традициями. Писатель, рожденный и воспитанный в районе Харькова, остающийся под сильным влиянием романтической идеи народности, не только выражал свои эстетические и теоретические взгляды во многих критических текстах, но также старался, по мере своих возможностей, воплощать их в литературу. В трактате $O$ романтической поэзии, популярном среди поэтов-декабристов, Сомов формулирует известный тезис, что «(...) народу русскому (...) необходимо иметь свою народную поэзию, неподражательную и независимую от преданий чуждых" (Сомов 1823: 146-147). Живыми источниками такой «народной поэзии» являются, по мнению писателя, «нравы, понятия и образ мыслей» народа, его культура и история. «(...) главное для романтика Сомова - дух народа, выражающийся в его поверьях и 
мифологических представлениях. Потому-то в его «небылицах» народные побасенки рассказываются как бывальщина, не подвергаются скептическому анализу, предание остается преданием, хотя и облечено в одежды повествования литературного» (Петрунина 1984:16). Так, выполняемая в Сомовской Русалке стилизация на жанр фольклора (произведение имеет подзаголовок: Малороссийское предание), относящаяся и к образу колдуна Боровика, является практической реализацией эстетической и теоретической подоплеки русского романтизма.

Что же касается влияния общеевропейской романтической традиции, то, главным образом, здесь следует учесть жанр готического романа, пользующегося огромным успехом в России 30-х г. XIX столетия. В образе колдуна Боровика прослеживаются, прежде всего, «френетические» элементы типичных героев романа ужасов: промежуточность статуса персонажа, находящегося на границе жизни и смерти; подчеркнутая внешняя непривлекательность героя; крайне отвратительная свита колдуна, экспонирующая демоническую природу его профессии и связь с силами зла; непредсказуемость поведения колдуна и неуверенность читателя в его роли (он помощник или вредитель?); таинственная обрядность магических действий; символика предметов и пространства; частое повторение эпитета страшный, и др. Все это вписывается в схему шоковой, перверсивной фантастики, свойственной готическому роману. Гротескный, безумный, страшный, противный, но в то же время приподнятый и серьезный образ колдуна вызывает у читателя подлинно романтическое напряжение, болезненное любопытство и предвкушение странного удовольствия ${ }^{6}$.

\section{Библиография}

Виноградова Л. Н. (2000): Народная демонология и мифо-ритуальная традичия славян, Москва: Индрик.

${ }^{6}$ Больше на тему романтической френезии в литературе см.: (Ritz 2009), а также фундаментальную работу Марио Праза (Praz 2010). 
Виноградова Л.Н., Левкиевская Е.Е. (ред.) (2010): Народная демонология Полесья. Публикации текстов в записях 80-90-х г2. ХХ века, т. 1: Люди со сверхъестественными свойствами. Москва: Языки славянских культур. (НДП1)

Виноградова Л.Н., Левкиевская Е.Е. (ред.) (2012): Народная демонология Полесья. Публикации текстов в записях 80-90-х г2. ХХ века, т. 2: Демонологизация умерших людей. Москва: Рукописные памятники Древней Руси. (НДП2)

Криничная М.А. (2004): Рукодельницы: магия прядения, вязания, плетения, в: Ее же: Русская мифология. Мир образов фольклора. Москва: Академический Проект, Гаудеамус, с. 463-493.

Мадлевская Е. (ред.) (2006): Русская мифология. Энииклопедия. Москва: Эксмо - Санкт-Петербург: Мидград. (РМЭ)

Максимов С. (2002): Нечистая, неведомая и крестная сила (фрагменты), в: Даль В. и др.: Русское колдовство. Москва: Эксмо - С.-Петербург: Terra Fantastica, c. 215-363.

Махов А. Е. (2013): Hostis antiquиs: Категории и образы средневековой христианской демонологии. Опыт словаря. Москва: Intrada.

Никитина Н. А. (2002): К вопросу о русских колдунах, в: Даль В. и др.: Русское колдовство. Москва: Эксмо - С.-Петербург: Terra Fantastica, с. 364-395.

От издателя (2002), в: В. Даль и др.: Русское колдовство. Москва: Эксмо- С.Петербург: Terra Fantastica, c. 5-6.

Петрунина Н.Н. (1984): Орест Сомов и его проза, в: Сомов О.М., Были и небылииы, Москва: Советская Россия.

Померанцева Э.В. (1975): Мифологические персонажи в русском фольклоре, Москва: Наука.

Сомов О. М. (1823), О романтической поэзии, в: Соревнователь, ч. 24, № 11, с. $125-147$.

Сомов О. М. (1984): Русалка. Малороссийское предание, в: Его же, Малороссийские были и небылицы, Москва: Советская Россия.

Cooper J.C. (1998): Zwierzęta symboliczne i mityczne. Warszawa: Dom wydawniczy Rebis.

Libera Z. (1987): Semiotyka barw w polskiej kulturze ludowej, в: Etnografia Polska, т. 31, выпуск 1, с. 115-138.

Pełka L. (1987): Polska demonologia ludowa. Warszawa: Iskry.

Praz M. (2010): Zmysty, śmierć i diabet $w$ literaturze romantycznej, Gdańsk: słowo/obraz terytoria. 
Ritz G. (2009): Romantyczna frenezja jako koncepcja obrazowania, в: Ławski J.,

Sokołowski M., Nihilizm i historia. Studia z literatury XIX i XX wieku. Białystok

- Warszawa: Wydawnictwo Uniwersyteckie Trans Humana, c. 141-170.

http://about-kiev.ru/povedai5.html (19.08.2013).

http://ru.wikipedia.org/Wiki/Рушник (19.08.2013).

http://wyborcza.pl/2029020,75400,11181061.html (19.08.2013). 